\title{
O DIREITO TRANSNACIONAL E A FORMAÇÃO DE NOVAS FORMAS DE PODER EM UMA SOCIEDADE DE CONTROLE INFORMACIONAL
}

\author{
TRANSNATIONAL RIGHT AND THE FORMATION OF NEW \\ FORMS OF POWER IN A INFORMATIONAL CONTROL \\ SOCIETY
}

\author{
Márcia Sleiman Rodrigues* \\ Augusto Eduardo Miranda Pinto ${ }^{* *}$
}

\begin{abstract}
SUMÁRIO: Introdução. 2 As técnicas disciplinares de controle. 3 Uma nova sociedade de controle a partir do biopoder. $4 \mathrm{O}$ poder da multidão e a inteligência coletiva no ciberespaço. Considerações finais. Referências.
\end{abstract}

\begin{abstract}
RESUMO: Deleuze aborda superficialmente o surgimento de uma nova sociedade de controle, ele afirma seguir Foucault, mas é difícil encontrar um desenvolvimento profundo da passagem da sociedade disciplinar para esse novo formato social. Ademais, as introduções dessas idéias por Deleuze são bem resumidas, mas nos aponta um caminho para o delineamento dos saberes envolvidos na construção dessa sociedade. Neste trabalho desenvolveremos os vários autores que tratam do respectivo tema, das interações com o mundo virtual e da formação de novas formas de poder em um contexto de um direito transnacional.
\end{abstract}

Palavras-chave: controle. poder. direito transnacional.

\begin{abstract}
Deleuze touches on the emergence of a new society of control, he affirms follow Foucault, but it is difficult to find a deep development of the passage from disciplinary society to this new social format. In addition, the introductions of these ideas by Deleuze are summarized, but points us a path to outline of knowledge involved in building this society. In this paper we will develop the various authors deal with its theme, the interaction with the virtual world and the formation of new forms of power in the context of a transnational right.
\end{abstract}

Keywords: control. power. transnacional right.

\section{INTRODUÇÃO}

* Graduada em Direito pelas Faculdades Integradas Cândido Mendes - Ipanema; Mestre em Direito pela Universidade Estácio de Sá - UNESA e Doutoranda em Direito pela Universidade Vale do Rio dos Sinos - UNISINOS; Coordenadora Geral do Curso de Direito da UNESA e Professora da Escola da Magistratura do Estado do Rio de Janeiro - EMERJ.

** Possui graduação em direito(2005) e mestrado em Direito pela Universidade do Estado do Rio de Janeiro(2007); e mestrado em Tecnologia com enfasê em educação, pelo CEFET-RJ (1998). Atualmente é Auditor Fiscal do Trabalho - Gerência Regional do Trabalho-Cabo Frio. Tem experiência na área de Direito, com ênfase em Direito do Trabalho, atuando principalmente na auditoria pública de empresa e na área de ensino. 
Deleuze aborda superficialmente o surgimento de uma nova sociedade de controle, ele afirma seguir Foucault, mas é difícil encontrar um desenvolvimento profundo da passagem da sociedade disciplinar para esse novo formato social. Ademais, as introduções dessas idéias por Deleuze são bem resumidas, mas nos aponta um caminho para o delineamento dos saberes envolvidos na construção dessa sociedade. Neste trabalho desenvolveremos os vários autores que tratam do respectivo tema, das interações com o mundo virtual e da formação de novas formas de poder em um contexto de um direito transnacional.

Analisamos a seguir as técnicas disciplinares de controle dos séculos XVII e XIX que instituiu fórmulas de dominação baseada em uma relação de utilidade e de uma política de obediência. Nesta sociedade disciplinar a visibilidade tem função primordial na sua arquitetura e se utiliza de uma utopia panóptica que incorpora um olhar central que todos vê e não pode ser visto. Esse instrumento melhora o exercício do poder e apesar de hermético, torna-o mais leve, rápido e eficaz, desenhando uma sociedade que estar por vir.

$\mathrm{Na}$ nova sociedade de controle não há finitude, é um contínuo movimento. A partir da introdução de novas tecnologias geramos novos padrões de gerenciamento e empregos, estando sempre em um ininterrupto condicionamento. As novas redes computacionais propiciam o fortalecimento da sociedade do espetáculo que a partir de idéias e imagens visam regular o discurso e a opinião pública. A cultura consumista é o grande incentivador dessa exposição excessiva reforçando a escolha de um estilo de vida que privilegia um inalcançável padrão de consumo que categoriza os indivíduos. Há uma transformação do sujeito em mercadoria, que somente a partir de determinado poder aquisitivo pode pleitear seus direitos, construindo sua subjetividade a partir desses parâmetros. Ocorre uma manipulação de nossas escolhas e condutas individuais, tendo o próprio Estado terceirizado suas funções e cedendo poderes ao mercado. As necessidades do acesso a novos produtos e patamares consumistas necessitam de uma fluidez muitas vezes que o governo não comporta, transformando o braço jurídico e legislativo em um mero executor das aspirações do modelo da empresa líquida moderna. Essa metodologia produz novas formas de poder e saber a partir de uma nova interação em rede, com um efeito global e aglutinador. Em face dessa expectativa globalizante visando à otimização do lucro, os usuários das redes sociais são submetidos à constituição de 
perfis que possam estabelecer padrões de consumo, ou servir para a alimentação de banco de dados para possíveis opções de empregos, com uma eterna vigilância e motorização constante.

O modelo consumista de produção impõe uma nova forma de poder global, que ligada a uma forma paradigmática de biopoder e biopolítica seria adequado à globalização e as relações econômicas e sociais vigentes, e que conseqüentemente, enfraqueceria os Estadosnação capitalistas dominantes. As novas configurações jurídicas desse modelo apresentariam uma construção de uma nova ordem mundial, com o objetivo de vivenciar uma transição da lei internacional tradicional para um direito transacional, na busca de uma paz social que estabelecesse uma ética de mercado universal.

A construção de uma força coletiva intitulada multidão se contrapõe ao estabelecimento de um governo único estabelecido pelas entidades supranacionais baseado no modelo produtivo, sem a participação de outros atores sociais. O que abordaremos a seguir e a possibilidade a partir do hibridismo homem-máquina podermos criar novas configurações de relações sociais, de modo a alterar o estabelecimento dessas formas de controle utilizadas pelas tecnologias informacionais.

\section{AS TÉCNICAS DISCIPLINARES DE CONTROLE}

Foucault ao analisar os séculos XVII e XIX aborda a formação das sociedades disciplinares, enfatizando este momento como $\mathrm{O}$ nascimento da arte do corpo humano não só para o aumento de suas habilidades, mas a criação de uma relação que o transforma em um corpo submisso, mais dócil, mais útil e obediente. Tais fórmulas de dominação já existiam há muito tempo: nos conventos e nas oficinas, mas a diferença está que neste momento há um aumento das forças do corpo em uma relação econômica de utilidade e uma diminuição nos termos da política de obediência. Essa nova política se faz através de uma multiplicidade de processos com técnicas especiais que tendem a se generalizar. "Técnicas sempre minuciosas, muitas vezes íntimas, mas que têm sua importância: porque definem um certo modo de investimento político e detalhado do corpo, uma nova $<<$ microfísica $>>$ do poder" (FOUCAULT, 1977, p. 128).

Esse olhar da inspeção, dos regulamentos, controlando as mínimas partes da vida, atua na escola, no quartel, no hospital e na 
oficina, sendo fechado através das disciplinas em um espaço analítico. Em uma ótica utilitarista, é necessário "anular os efeitos das repartições indecisas, o desaparecimento descontrolado dos indivíduos, sua circulação difusa, sua coagulação inutilizável e perigosa; tática de antideserção, de antivadiagem, de antiaglomeração" (FOUCAULT, 1977, p. 131), ou seja, a busca incansável pela eficiência.

A disciplina organiza o corpo por individualização, mas não é necessariamente implantada, é distribuída, se faz circular em uma rede de relações. Podemos apontar as oficinas quanto os trabalhadores são classificados em função de suas habilidades, rapidez e qualidade do trabalho (no caso de uma fábrica fordista), ou na escola quando as salas são divididas por fileiras, sob olhares do mestre, com componentes individualistas. Neste conjunto de alinhamentos, muitas vezes, pode-se identificar uma hierarquia de saber ou capacidades, ou ainda, traduzir espacialmente uma repartição de valores e méritos. $\mathrm{O}$ aprendizado tem um plano obrigatório, com uma ordem de dificuldade crescente, se encontrando conforme suas idades e de conformidade ao estabelecido na legislação educacional. $\mathrm{Na}$ faculdade, com os sistemas de crédito, "os indivíduos substituem uns aos outros, num espaço escondido por intervalos alinhados" (FOUCAULT, 1977, p. 134). A sua correta aplicação é o adestramento, é um exercício de poder que ao invés da apropriação e retirada, adestra para retirar e apropriar melhor.

Esse espaço serial é recorrente nas sociedades de disciplina fazendo estas escolas em máquinas de ensinar, de vigiar, de hierarquizar e de recompensar, em um sistema fechado, separando cada um, segundo seu temperamento, aplicação, limpeza e fortuna dos pais. Um sistema único sob olhar classificador do professor, mas, sobretudo, dos próprios colegas em sala. O poder disciplinar é totalmente indiscreto e está em toda a parte. Apesar de existir a figura do chefe ou do professor pela sua estrutura piramidal, não é este que detém o poder, mas a composição espacial que o abarca. Não deixa nada as escuras, sua visibilidade e transparência controlam continuamente a todos, pois funciona permanentemente e em grande parte em silêncio (FOUCAULT, 1977, p. 158).

Esse novo formato de relações tem por objetivo construir uma máquina cujo objetivo é obter um aparelho eficiente, que sempre estabelecesse uma determinada localidade de atuação, diferentemente da sociedade de controle constituída posteriormente, que é mais fluida, sem limitação espacial. Diferentemente, o processo disciplinar produz "quatro 
características: é celular (pelo jogo da repartição espacial), é orgânica (pela codificação das atividades), é genética (pela acumulação do tempo), é combinatória (pela composição das forças)." (FOUCAULT, 1977, p. $150)$.

O sucesso dessa técnica que fabrica indivíduos, os transformando em objetos, é um poder modesto funcionando de modo permanente. Seu sucesso tem uso de "instrumentos simples: o olhar hierárquico, a sanção normalizadora e sua combinação num procedimento que lhe é especifico, o exame" (FOUCAULT, 1977, p. 153). É necessário para o seu exercício, o jogo do olhar e o estabelecimento de um aparelho que pudesse induzir os efeitos desse poder e apresentar os meios de coerção de maneira clara para aqueles que a eles são submetidos. Uma peça interna importante desse aparelho é a vigilância, que atua como um operador econômico, sendo engrenagem do poder disciplinar. Importante seu papel, pois faz parte de um sistema integrado, organizando-se como um poder múltiplo, automático e anônimo, autuando em uma rede de relações de alto a baixo; e de baixo para cima, inclusive lateralmente, onde todos são vigiados, os fiscais e os fiscalizados.

Benthan em 1785 descreveu uma máquina arquitetônica que a princípio atenderia estes propósitos, com uma visão utilitarista, apresentou o 'panóptico' como uma solução para todos os males. Sua utilização poderia ser feita nas escolas, hospitais e prisões. Seria:

[...] na periferia uma construção em anel; no centro, uma torre; esta é vazada de largas janelas que se abrem sobre a face interna do anel; a construção periférica é dividida em celas, cada uma atravessando toda a espessura da construção; elas em duas janelas, uma para o interior, correspondendo às janelas da torre; outra, que dá para o exterior, permite que a luz atravesse a cela de lado a lado. Basta então colocar um vigia na torre central, [...] A plena luz e o olhar de um vigia captam melhor a sombra, que finalmente protegia. A visibilidade é uma armadilha. (FOUCAULT, 1977, p. 177).

A onipresença aparente do inspetor combina com sua real presença, diminuindo a necessidade de um número excessivo de inspetores, para um máximo de vigiados e um mínimo de vigilantes. Os subinspetores e os subguardas estarão sob o controle do inspetor-mor, assim como os outros prisioneiros (BENTHAM, 2000, p.26). Cada cela se apresentava ao mesmo tempo para o interior e o exterior, o olhar do 
vigilante a atravessava como um todo, mas este não podia ser visto, apenas observava através das persianas, podia ver tudo sem que ninguém ao contrário pudesse vê-lo. Mas, não é uma prisão, é um princípio de construção, "a máquina óptica universal das concentrações humanas [...]. Ela tem uma destinação única: é a casa dos habitantes involuntários, reticentes ou constrangidos" (BENTHAM, 2000, p.77). O exercício da vigilância permanente é a utopia panóptica, também usado no romance de George Orwell, onde o 'big brother' incorpora este olhar central que todos vê e não pode ser visto.

A visibilidade tem função primordial na arquitetura do seu sistema, há uma dessimetria brutal no percurso da luz. O espaço é fechado, sem esconderijos, com total transparência. Há um olho único central, nada se dissimula, senão sua presença invisível e ele se apropria do poder de ver, de maneira onisciente. No seu anel circular é a luz que aprisiona. Este olho vê, sem ser visto. Quando conheço meu observador posso dominá-lo, domino a vigilância, aprendendo seus deslizes, assim, eu também o espio e posso encontrar suas fraquezas. Mas, no panóptico o inspetor se esconde na sombra, é o jogo da aparência, seus poderes criam uma figura onipresente, onividente, aumentando a dependência dos subordinados, como um Deus artificial (MILLER, 2000, p. 78). Ele é governado por uma voz e um olhar desconectado do seu portador, o inspetor, como uma entidade ficcional, se transforma em um fantasma que através do medo exerce um poder maior que o guarda real, por mais cruel que fosse.

Não há uma coletividade definida, mas as individualidades se fundem, induzindo no detento um estado permanente de observação que garante um funcionamento automático do poder. Transparência, classificação, cálculo, utilização geral, tais valores exigem a certeza das identidades. Os valores presentes apontam que para o preso somente a solidão e não há a necessidade que saiba efetivamente que esteja sendo observado, pois desconhece se há na cabine central, efetiva vigilância. "Visível: sem cessar o detento terá diante dos olhos a alta silhueta da torre central de onde é espionado. Inverificável: o detento nunca deve saber se está sendo observado; mas deve ter certeza de que sempre pode sê-lo." (FOUCAULT, 1977, p. 178). Esse poder pode ser exercido por qualquer pessoa, pelo diretor, sua família, amigos e até visitas. Quanto maior o número de anônimos e passageiros que tenham o prazer em espionar, tanto maior o risco do prisioneiro ser surpreendido cometendo uma falta. A partir dos desejos mais estranhos criam-se efeitos 
homogêneos de poder.

Bentham quer acabar com as correntes, com as grades e fechaduras pesadas, criando uma sujeição real a partir de uma relação ficta. Aproveitando-se de uma geometria simples, o edifício funciona espontaneamente sobre si mesmo, de maneira incorpórea e invisível. É um grande laboratório, para exercer a experiência com homens, podendose analisar as transformações que se obtém a partir deles em sua vida cotidiana. Através de uma relação hierárquica se impõe uma tarefa ou um comportamento a uma multiplicidade de indivíduos, criando a utopia do encarceramento perfeito através de uma tecnologia política (FOUCAULT, 1977, p. 180-181).

É o templo da razão, pois não tem nem sombra, nem recanto, sua luminosidade acusa a uma inspeção permanente, mas também uma racionalidade que se impõem a partir do totalitarismo. Sua função é se dedicar à utilidade, ao máximo do rendimento. As visitas aos presos podiam ser aleatórias e incessantes, inclusive abertas ao público, ou qualquer membro da sociedade poderá participar do espetáculo. E como evitar que estes sejam discriminados quando colocados em liberdade? Os presos podiam usar máscaras, que poderiam ser mais ou menos trágicas, dependendo de seus delitos. Um verdadeiro teatro do castigo, como se fosse um circo romano, inclusive com acesso a um grande número de pessoas.

Mas, quem guarda os guardiões? O Olho público vigia o interior, a partir do espetáculo, ocorre o controle de toda a organização. Os visitantes vigiam o inspetor e igualmente os detentos. A vigilância invisível também é vigiada, tudo através do espetáculo, da curiosidade humana e do sofrimento alheio (MILLER, 2000, p. 83).

Para Bentham, importa menos o efeito de quem é castigado, e mais as impressões daqueles que o vêem ou são informados. Tal exposição teria também um caráter moralizador, pois pela vergonha dos prisioneiros aumentaria a sua recuperação. Na sua visão a pena deve ter uma função em si mesma. O sofrimento extraído dela deve produzir um trabalho produtivo. Quando necessária, deve ser mecanizada, como sua máquina de chicotear, de modo que um grande número de prisioneiros suportasse suplícios ao mesmo tempo, de maneira igual e eficiente (MILLER, 2000, p. 84).

O utilitarista é um observador de cada objeto. A partir do seu olhar ele o totaliza e depois o desnaturaliza, decompõe em partes, e em seguida o monta de maneira a maximizá-lo. Sempre o que permeia o seu 
objetivo é o princípio do máximo. Esse modelo a ser alcançado é essencialmente variável, sempre busca a reforma e com isso o melhor. Seu objetivo é o todo, o universo, a humanidade. Essa visão totalitarista tem um objetivo filantrópico à busca de um novo império, onde prevaleça o máximo, em todos os lugares e em tempos por vir, englobando toda espécie humana.

Podemos a princípio acreditar na incompatibilidade entre o utilitarismo benthaniano e a sociedade do espetáculo, pela redução do primeiro de toda estética e ostentação. Mas, neste caso a arte teatral é um modelo de ciência útil, com uma finalidade específica. Bentham em suas palavras demonstra a importância do olhar alheio:

Predicai ao olho, se quereis predicar com eficácia. É por
este órgão, pelo canal da imaginação, que o julgamento da
maioria da humanidade pode ser conduzido e modelado
quase que à vontade. Como marionetes na mão do feirante,
assim serão os homens na mão do legislador que, além da
ciência própria à sua função, deveria prestar uma atenção
cultivada ao efeito teatral. (BENTHAM, Jeremy apud The
rationale of evidence, publicada por Bowring no vol. II
apud MILLER, 2000, p. 89).

Segundo categorização de Foucault passamos de uma sociedade de soberania, onde o rei exercia o poder através de uma vigilância externa para a sociedade disciplinar, na qual as instituições têm maior internalização, através de lugares fechados. Ele considerava a sociedade disciplinar um microcosmo da sociedade do século XIX em contraponto ao antigo regime, que se expressava pelas exibições teatrais da autoridade soberana, onde o rei exercia o poder externando sua política do espetáculo, tal como na execução pública. Com a exibição dos presos no sistema panóptico, com suas máscaras e um povo sedento de conhecer o bizarro, há uma idealização do espetáculo preconizada por Guy Debord, o que em parte contraria a incompatibilidade apresentada por Foucault (WERRET, 2000, p. 154).

Este modelo é apresentado como um laboratório de poder, que através de mecanismos de observação ganha a capacidade de penetrar o comportamento humano e descobrir "objetos que devem ser conhecidos em todas as superfícies onde este se exerça" (FOUCAULT, 1977, p. 180). Seu principal objeto nesta nova anatomia política não são as relações de soberania, mas as relações de disciplina. "Ele programa, ao nível de um mecanismo elementar e facilmente transferível, o funcionamento de base 
de uma sociedade toda atravessada e penetrada por mecanismos disciplinares." (FOUCAULT, 1977, p. 184). Esse instrumento melhora o exercício do poder tornando-o mais leve, rápido e eficaz, desenhando uma sociedade que estar por vir.

\section{UMA NOVA SOCIEDADE DE CONTROLE A PARTIR DO BIOPODER}

A partir da interpretação de Deleuze passamos de uma sociedade disciplinar para uma sociedade de controle. O próprio Foucault já previa a crise deste modelo e apontava para uma outra forma de gerenciamento do poder. "Nesses últimos anos, a sociedade mudou e os indivíduos também; eles são cada vez mais diversos, diferentes e independentes. Há cada vez mais categorias de pessoas que não estão submetidos à disciplina, de tal forma que somos obrigados a pensar o desenvolvimento de uma sociedade sem disciplina" (FOUCAULT, 2003, p. 268).

Nos séculos XVIII e XIX tiveram seu foco às sociedades disciplinares, o indivíduo passava de ambientes fechados durante toda a sua vida, da casa para escola, da escola para caserna e da caserna para fábrica. $\mathrm{O}$ confinamento era seu habitat natural por excelência. Esse modelo, sucedido das sociedades de soberania, era uma modelagem fixa, que sofreu uma crise generalizada após a segunda guerra mundial, suscitando a necessidade de um novo formato mais flexível, movente, que deu origem às novas sociedades de controle. Essa se apresenta como se mudasse continuamente, a cada instante, em estado perpétuo de metaestabilidade. Em um mundo globalizado os salários são flutuantes, os empregos e as profissões se renovam continuamente, com a substituição da fábrica pela empresa se torna mais livre das amarras de um sistema fechado em si mesmo. Na fábrica no modelo anterior, os indivíduos representavam um só corpo, com o patronato de um lado e os sindicatos do outro. Na empresa com a nova modelagem variável se introduz a rivalidade eterna, a busca por um salário unicamente a partir do mérito prejudica a própria educação, pois acaba com a substituição da empresa pela escola e a uma exigência do mercado por uma formação constante, a partir de um controle contínuo que substitui o exame. $\mathrm{Na}$ nova sociedade tudo é monitorado e vigiado, não mais pelo exame físico, mas virtual (DELEUZE, 1990, p. 223-225).

$\mathrm{Na}$ sociedade de controle não se termina nada, há sempre novas tecnologias, novos padrões de gerenciamento, estamos sempre em um ininterrupto condicionamento. Buscando novos produtos, novos 
empregos, novos serviços, todos como um deformador universal a partir de estados metaestáveis de uma mesma modulação. Enquanto na sociedade disciplinar tínhamos a assinatura que identificava o indivíduo, e a matrícula que o posicionava na massa. Nas de controle o referencial é a senha, que marca o acesso à informação, ou sua rejeição. Os indivíduos perdem seu lugar na massa, são divisíveis, deixam de ser um corpo único transformando a massa em amostras, dados, mercados ou bancos. Até o dinheiro muda conceitualmente nesta nova sociedade, não são mais moedas cunhadas em ouro, mas trocas flutuantes a partir de um mercado de ações globalizado. As máquinas também se alteraram, tendo em vista que exprimem as formas sociais que lhes deram origem. Na sociedade de soberania eram máquinas simples, como alavancas, relógios e roldanas, já nas disciplinares tínhamos máquinas energéticas; e na de controle operamos por máquinas de informática e computadores. Tal se dá pela mutação do próprio sistema capitalista, que passa do empresário detentor dos meios de produção (algumas vezes da própria casa do operário) para o da especialização, colonização e redução dos custos de produção. Temos agora um capitalismo de sobreprodução, que não é dirigido para produzir matérias primas ou produtos acabados, mas para venda de serviços e compra de ações. Somos agora não mais homens confinados, mas endividados. Uma nova forma de controle, utilizando as novas tecnologias mediáticas, tem dissipado as fronteiras, mas causadas desigualdades (DELEUZE, 1990, p. 226-228).

A fábrica foi substituída pela empresa, não se converge mais este espaço analógico para o proprietário, bem como nem a escola, nem a família, a sucessão de espaços fechados da sociedade disciplinar deu lugar à liquidez da sociedade de controle. Tudo está interagindo rapidamente em face de uma visão gerencial, de especialização da produção, enfatizando o marketing como instrumento de controle social. Ele age de maneira rápida enquanto a disciplina era de longa duração, infinita e descontínua (DELEUZE, 1990, p. 228).

Esta nova sociedade de vigilância tem sua formatação facilitada não só pelos atores sociais envolvidos, mas pela tecnologia disponibilizada para tal. A cidade idealizada por Gattari "onde cada um pudesse deixar seu apartamento, sua rua, seu bairro, graças a um cartão eletrônico (dividual) que abriria as barreiras; mas este poderia também ser recusado em tal dia, ou entre tal e tal hora" (DELEUZE, 1990, p. 229) aponta uma categorização dos indivíduos, com um controle específico do direito de ir e vir e se subordina a determinados interesses, formatações 
sociais e aspectos de detenção de poder, caminhando tal estrutura para substituição das sociedades disciplinares. Esse novo modelo abarca algumas características da sociedade de soberania, mas com adaptações. No lugar das prisões apresentaríamos as penas substitutivas e as coleiras eletrônicas, com controle panóptico à distância. Nas escolas, teríamos a introdução do conceito empresarial nos seus muros, com as pesquisas universitárias ligadas apenas à ótica lucrativa, ou o seu total abandono. Nos hospitais com seu padrão de exclusão, que afasta doentes potenciais ou de riscos e prioriza equipamentos de alta tecnologia em detrimentos de ações individuais de prevenção, substitui o corpo individual pela cifra 'dividual' a ser controlada. Ademais, iniciasse a partir da renda do usuário a classificação em grupos com acessibilidade a determinados exames, a hospitais de qualidade, e ao tempo de espera para determinados procedimentos mais custosos, o que pode monetarizar o próprio acesso à saúde e a chance de sobrevivência. No regime da empresa, com a alteração da fábrica taylorista-fordista para um regime mais fluídico que tem novas maneiras de tratar o dinheiro e de empregabilidade, se privilegia novas formas excessivas de terceirização e precarização da mão de obra. A partir desses exemplos se deslumbra novas formas de dominação e uma crise das instituições (DELEUZE, 1990, p. 230).

Hardt observa que na passagem da sociedade disciplinar para a sociedade de controle não existe antinomia, mas uma continuação da mesma lógica, com outros instrumentos. Desenvolvendo o pensamento de Deleuze apresentasse diversos pontos para esta mudança: o enfraquecimento da sociedade civil, com o declínio das funções mediadoras das instituições sociais; a passagem de uma nova ordem mundial, em função das empresas transacionais e do enfraquecimento do Estado-nação europeus; e, sobretudo uma nova forma de sociedade de controle mundial, que se utiliza de tecnologias informacionais para estender seu modelo para todas as civilizações (HARDT, 2000, p. 357). Passa do espaço estriado para o espaço liso, se valendo de uma nova configuração espaço-tempo a fim de exercer um controle efetivo a partir de redes flexíveis e montagens de perfis, estabelecendo a categorização dos indivíduos por classe social, renda, escolaridade, habitação, reafirmando a figura do consumidor global.

$\mathrm{Na}$ pós-modernidade o mercado mundial tende a desconstruir as fronteiras do Estado-nação. Enquanto anteriormente seu papel era dominante na produção e intercâmbio global, em um futuro próximo não 
teremos mais tecnologias ou corporações nacionais, virá um novo conceito, construído a partir de redes globais de poder, com estruturas móveis e diferenciadas, a partir de uma lógica própria do capital global. As práticas de marketing e o consumo enfatizam as imagens transformadas em mercadorias definindo a experiência na pósmodernidade através de uma nova jornada coletiva da hiper-realidade. "O marketing pós-moderno reconhece a diferença de cada mercadoria e de cada segmento da população, elaborando suas estratégias apropriadamente. Toda diferença é uma oportunidade" (HARDT; NEGRI, 2010, p. 170).

Nesse contexto, com a passagem da modernidade para pósmodernidade, a soberania que foi concebida em uma sistemática espacial, em termos de território imaginário ou real perde força e diminuem-se as diferenças com o conceito de 'fora'. A nova formatação do ciberespaço proporciona cada vez menos distinções entre dentro e o fora, com uma mudança geral do espaço circunscrito pelo qual o poder se impõe. Essa dialética entre dentro e fora, que os primeiros teóricos modernos como Hobbes e Rousseau compreendiam como uma espaço limitado da ordem civil em contraponto a ordem exterior da natureza está chegando ao fim. Neste novo mundo os fenômenos e forças são artificiais e os espaços públicos da sociedade moderna tendem a diminuir. Na tradição liberal o indivíduo enquanto nos seus espaços privados, considerava o público como fora. Este era próprio da política, onde o indivíduo era exposto ao olhar alheio, e procurava seu reconhecimento (HARDT; NEGRI, 2010, p. 207).

Há cada vez mais a privatização do espaço público, não é mais possível manter a dialética, espaços privados e públicos (dentro e o fora). As praças se esvaziaram alterando a passagem urbana, acabando com os encontros casuais e o agrupamento de todos. Com a comunicação móvel, os aspectos de territorialidade foram alterados, podendo-se localizar uma pessoa em qualquer lugar e a qualquer tempo. Ademais, com Facebook, Orkut e Myspace sua vida pessoal é exposto através de fotos, encontros, e até opiniões de terceiros sobre diversos assuntos em tempo real. Como o espaço público era o local da política, ocorre um esvaziamento dessa atividade com o advento do ciberespaço, proporcionando um afastamento dos jovens e transformando a organização social como nós a conhecíamos (HARDT, 2000, p. 359-360). Perdemos a teatralidade do antigo regime e a substituímos pela sociedade do espetáculo de Guy Debort. 
O que o espetáculo oferece como perpétuo é fundado na mudança, e deve mudar com sua base. O espetáculo é absolutamente dogmático e, ao mesmo tempo, não pode chegar a nenhum dogma sólido. Para ele, nada pára; este é seu estado natural e, no entanto, o mais contrário à sua propensão. (DEBORD, 1997, p. 47).

Esta sociedade do espetáculo é um lugar virtual, ou seja, um não lugar da política. Ela é simultânea, unificada e difusa, de maneira que não é mais possível distinguir o dentro do fora, o natural do social ou o privado do público. Não há mais a noção que o olhar de fora é o lugar liberal do público, onde agimos sob olhar dos outros, esta noção tornouse universalizada, pois estamos sempre a ser observados, por câmeras de vigilância, por celulares prontos para clicar uma foto, ou pelo GPS que carregamos embutidos em nossos telefones, estamos em um território desrealizado, nos espaços virtuais do espetáculo (HARDT, 2000, p. 359$360)$.

Essas novas redes híbridas de interação aumenta a formação do espetáculo, com idéias e imagens que regulam o discurso e a opinião pública. Nesta sociedade a participação política se esvai, ele destrói formas coletivas de socialização, individualizando as pessoas através dos seus bens consumíveis e da ideologia inerente a eles. Desta maneira impõe uma nova socialidade de massa, com uma uniformização de pensamento e ação. A política se resume na escolha de imagens consumíveis. $\mathrm{O}$ modo do estabelecimento dessa cultura, que funciona na satisfação dos desejos e prazeres, ocorre em uma cultura do medo, de não ser aceito, de não se estabelecer perante os parâmetros sócio-econômicos, criando uma permanente inadequação criada pela constante manipulação da mídia e os valores por ela criados. É como se "a mídia, as forças armadas, o governo, as empresas transacionais, as instituições financeiras globais, e assim por diante, fossem todos conscientes e explicitamente dirigidos por um único poder, apesar de não o serem" (HARDT; NEGRI, 2010, p. 344).

A cultura consumista é o grande baluarte dessa exposição excessiva, essa nova sociedade de consumidores reforça a escolha de um estilo de vida que promove uma determinada estratégica existencial e rejeita outras opções culturais. Há uma necessidade de se adaptar a este modelo de maneira incondicional.

Esse novo mercado capitalista tende a diminuir a noção de dentro 
e fora. A otimização do lucro prevê um mercado mundial dentro de uma categorização cada vez maior dos consumidores. O próprio conceito de consumir traduz-se em uma maneira de se situar dentro da pirâmide social. Dependendo do que se compra, da maneira que se veste, do carro que se usa, pode se oferecer como um produto mais apresentável, ou seja, você também se transforma em uma mercadoria. Neste caso, busca o indivíduo a partir do mercado adquirir habilidades, ou reciclar as que já possui, a fim de ser mais 'vendável'. O sujeito se transforma em mercadoria e dependendo do seu poder aquisitivo pode passar pelo teste de admissão. É a "pré-condição de todas as relações contratuais que tecem a rede de relacionamentos chamada 'sociedade de consumidores' e que nela são tecidas. A possibilidade de sua recusa, que consolida o agregado das transações de compra e venda numa totalidade imaginada" (BAUMAN, 2007, p. 76).

A sociedade de consumidores está sempre em movimento manipulando as escolhas e condutas individuais. Diferentemente da sociedade de produtores que a precedeu, que era orientada para a segurança e que se baseava em um modelo societário de base sólida. Esta face anterior era fundamentada nas fábricas e exércitos em massa, de regras obrigatórias e uma total submissão a partir das disciplinas, como abordado por Foucault. Era um poder que se utiliza da vigilância constante através da coerção material, exercido como um mecanismo de dominação independente da existência física de um soberano baseandose na padronização do comportamento individual, tendo como instrumento a disciplina e a subordinação.

Essa sociedade de produtores visava à satisfação a longo prazo. Os consumidores economizavam hoje para colher frutos futuros e não no desfrutar imediato dos prazeres. Adiavam-se o consumo de bens que ofereciam conforto e segurança, quase indefinidamente, somente utilizando os quando surgisse a real necessidade de usá-los. Somente bens duráveis e imunes ao tempo poderiam oferecer uma perspectiva de um futuro seguro e confiável. No início do século $\mathrm{XX}$ o consumo excessivo era desprezado e incentivava-se a exibição pública de riqueza, com ênfase na solidez e segurança, considerando-se que os prazeres efêmeros, quando usados e saboreados poderiam levar a destruição. $\mathrm{O}$ lucro e a exibição estavam ligados ao grau de solidez e a indestrutibilidade dos bens adquiridos, como ouro e metais preciosos que não perdiam o brilho e nem oxidavam, representando a confiabilidade, permanência e durabilidade contínua. Mas em uma sociedade de 
consumidores a busca da felicidade não se atinge com uma perspectiva remota de satisfação de desejos, mas a uma busca imediata em uma intensidade de desejos sempre crescentes, com uma constante substituição de objetos já obsoletos. Para garantir o contentamento de novas necessidades são necessárias novas mercadorias, que asseguram uma tendência ao consumo instantâneo e ao descarte. Essa modernidade líquida é contrária ao armazenamento a longo prazo, sua mobilidade se transforma em posição e respeito, desprezando bens volumosos como cargas preciosas (BAUMAN, 2007, p. 42-45).

O tempo também é fator predominante nesta passagem de paradigma. $\mathrm{Na}$ "era consumista o motivo de pressa é, em parte o impulso de adquirir e juntar. Mas o motivo mais premente que torna a pressa de fato imperativa é a necessidade de descartar e substituir." (BAUMAN, 2007, p. 50). O novo é sempre desejado, mas pressupõe que as promessas do mercado não atingiram seu propósito com o antigo produto. Há sucessivas tentativas fracassadas para se atingir um novo desejo com promessas sendo quebradas continuamente, mas as expectativas anteriores deixam de oferecer a satisfação pretendida e logo são abandonadas. É importante nesta economia consumista que o dinheiro mude de mãos, e faz parte do seu marketing que o cliente se separe do seu dinheiro o mais rápido possível para uma outra rodada de compras. Apesar da promessa de uma vida feliz, é a melancolia que se apresenta como uma constante nesta ânsia desenfreada por adquirir mercadorias. Não há como se comparar graus de felicidade de uma cultura em relação à outra, também não há como se afirmar se a revolução consumista ou o aumento geral de consumo em algumas regiões tornam as pessoas mais felizes, mas a promessa de uma felicidade plena e a busca por prolongadas jornadas de trabalho para atingi-la, seguido da insegurança e o desconforto de um padrão que o torne socialmente aceito, tem acarretado depressão, stress e deixa a dúvida quanto à efetividade deste modelo.

Seu desenvolvimento ocorre principalmente quando se consegue tornar perpétua a não satisfação de seus membros. Um de seus métodos é a depreciação e desvalorização dos produtos decorrido um determinado período de seu lançamento. As promessas já feitas, atraentes e cativantes são quebradas, apresentando um novo produto através de uma propaganda agressiva, o que com pequenas diferenças oferecem um patamar de satisfação mais adequado. Apesar da frustração da mercadoria comprada e que não atende suas expectativas, o ciclo se repete como um 
vício, e é logo ultrapassado com novas aquisições. Prevalece o desperdício econômico e a irracionalidade dos consumidores é estimulada pela emoção consumista em detrimento da razão. A atração constante de sucessivas compras é sempre a ilusão de um novo renascer surgindo à construção de uma auto-identidade a partir do mercado, onde planos de longo prazo fogem ao real e a desregulamentação da conduta humana acarreta a fragmentação dos seus vínculos e a privatização de seus desejos para uma suposta 'mão invisível' do mercado. Seu papel é encurtar a expectativa do desejo imediato e a distância temporal para alcançar a satisfação envolvendo velocidade, excesso e desperdício. Não há nenhum melindre quanto ao descarte contínuo, aceitando a vida curta das coisas e sua morte prematura com prazer, às vezes até com uma alegria de coisa renovada, um regozijo pelo novo. Essa síndrome consumista incentiva à negação da vantagem do retardamento da satisfação e da procrastinação a fim de alcançar benefícios futuros, em contraponto da síndrome produtivista da sociedade dos produtores. Estes consumidores tradicionais (que tiveram seu apogeu na era da produção taylorista-fordista) foram guiados pela garantia de desejos realistas e necessidades genuínas, sendo estes os verdadeiros inimigos dessa nova coletividade líquida de consumo (BAUMAN, 2007, p. 63-65).

A preocupação do consumidor, ainda que latente, é continuar sendo uma mercadoria vendável perante seus empregadores. A busca dessa meta, através da aquisição de carros, produtos de beleza, vestimenta e habitações adequadas desencadeiam as ações de consumo para o enquadramento no padrão de exposição social necessária para sua inclusão ou mantebilidade no mercado de trabalho.

Participar dessa sociedade demanda um esforço interminável. $\mathrm{O}$ medo da inadequação em função das exigências do mercado fornece as ferramentas necessárias para um contínuo trabalho de 'autofabricação'. "Só as mercadorias podem entrar nos templos de consumo por direito, seja pela entrada dos 'produtos', seja pela dos 'clientes'. Dentro desses templos, tanto os objetos de adoração como os adoradores são mercadorias" (BAUMAN, 2007, p. 82). A mecânica se perfaz quando o consumidor é atraído pelas lojas buscando o combustível que pode (e deve) ser consumido para ser aceito pelo o mercado que se apresenta. Neste processo ele procura o preço 'ótimo' e faz tudo a seu alcance para atingir o ápice de uma determinada tabela classificatória (seja do emprego, na escola do filho ou no clube de golfe), que depois de alcançada busca novos patamares de expectativa em um incessante fluxo 
que nunca tem sua satisfação saciada (BAUMAN, 2007, p. 76/81).

Desde o berço os consumidores são naturalmente legitimados por um "fundamento não jurídico da lei, já que precede todos os pronunciamentos legais que definem e declaram os direitos e obrigações do cidadão" (BAUMAN, 2007, p. 82). Desde a infância somos marcados para o consumo, nossa subjetividade é formada com uma estrutura para observação desse comportamento, de maneira a alterar o cogito descartiano, de 'Penso logo existo' para a 'Penso logo consumo'. É como se tal fosse um produto da natureza, não necessário de qualquer pronunciamento legal. Os legisladores não o consideram como um 'construto jurídico' mas como uma predisposição inata que todos somos obrigados a obedecer, proteger e servir. Como um direito fundamental do cidadão, sendo o comprometimento dos direitos secundários necessários apenas para torná-lo pleno e verdadeiramente inalienável (BAUMAN, 2007, p. 83).

Essa abordagem consumista reforça que o Estado terceirize muito de suas funções, cedendo poderes ao mercado. Ele assume como seu princípio político o padrão da vida cotidiana da sociedade de consumo. As necessidades do acesso a novos produtos e patamares consumistas necessitam de uma fluidez que o Estado muitas vezes não comporta, aumentando a separação entre o poder e agir, e direcionando os respectivos poderes para objetivos em que a política seja exercida cada vez com menos liberdade e capacidade de estabelecer a regra do jogo. $\mathrm{O}$ respectivo modelo acaba aumentando a política de exclusão, transformando o braço jurídico e legislativo em um mero executor da soberania dessa empresa líquido moderna (BAUMAN, 2007, p. 87/89).

$\mathrm{O}$ dever ético e a preocupação moral com o terceiro vista como uma responsabilidade reconhecida, assumida e concretizada foi afastada para o reino da auto-realização e do cálculo dos riscos. A partir destes se avalia cada decisão tomada em função da perda econômica que pode ocorrer ou do ganho em curto prazo. As responsabilidades são idealizadas em função de si próprias e não perante os outros e as escolhas responsáveis atendem nossos interesses buscando apenas a satisfação e os desejos do eu. Esse excesso de possibilidades consumistas em detrimento da rigidez da sociedade disciplinar, com excesso de proibições, acarreta um terror da inadequação, ao invés da culpa gerada pela quebra de regras no modelo antigo (BAUMAN, 2007, p. 119-122). A atividade permanente, uma urgência após a outra, dá a segurança de uma vida plena ou de uma carreira de sucesso, únicas provas de auto-afirmação 
num mundo em que as referências ao transcendente estão ausentes e onde a existência, com sua finitude, é a única certeza.

A imediatividade dessa sociedade exige aprendizado rápido, mas leva a obrigatoriedade do esquecimento também. O ciberespaço exige uma rede de fluxo inesgotável, com um ritmo alucinado de informação, onde o descarte constante é necessário para o novo que se inicia. Enquanto Castells saúda a nova tecnologia virtual como uma cura da solidão e Levy inaltece sua característica de interação coletiva e de rede global, Brauman enfatiza "que a rede parece, de maneira perturbadora, uma duna de areia soprada pelo vento e não um canteiro de obras onde poderão se estabelecer vínculos sociais confiáveis." (BAUMAN, 2007, p. 137). Ainda, afirma que as redes eletrônicas inseridas no mundo consumidor não utilizam o atributo da desconexão eletrônica como facilidade para estabelecer contato, ou de estar junto com várias pessoas ao mesmo tempo, mas abandonam a socialização face a face para inserirse numa sociedade onde prevalece a ótica do mercado e principalmente o princípio de uma rejeição ao indesejado, em uma relação muitas vezes superficial, desprezando as habilidades necessárias para estabelecimentos de vínculos sociais duradouros.

O autor enfatiza que a teorização sobre a internet não assinala um novo meio de engajamento político e que sua conexão não proporciona efetivo avanço democrático. Pelo contrário, acarreta o abandono da política realística e aponta a um crescente 'fetichismo da comunicação'. Ele entende que o fluxo informacional é mais um canal de indigestão do que um afluente do rio da democracia. Os servidores do mundo acumulam informação para que os internautas possam enfatizar a cultura do esquecimento como força motriz na vida dos consumidores. $\mathrm{O}$ debate político real se perde na política líquido-moderna, de maneira que esta não sofra influências, nem interrupções, nem confrontos, mas se manifeste apenas de modo descontextualizadamente e por meio de imagens. Esta dicotomia política corre em direções opostas, transformando a realidade em algo estéril, neutro e irrelevante (BAUMAN, 2007, p. 139-140).

A construção de uma identidade individual na sociedade de consumidores e no ciberespaço apresenta uma necessidade de se fazer conhecido. Não há identidades herdadas, ou de nascença, elas são projetadas e idealizadas a uma finalização longínqua e remota. Ainda que haja um arcabouço das identidades fornecidas inicialmente (por meio da família, ou posses, ou ainda uma determinada cultura), há a necessidade 
de se realizar um esforço para sua apropriação e continuidade, tendo em vista a exigência do mercado a um determinado padrão. Os consumidores são obrigatoriamente levados e pressionados a serem transformados em mercadorias atraentes e a utilizarem uma prática de marketing para atingir este propósito. "Os mercados fazem o possível para tornar a tarefa mais assustadora, e ao mesmo tempo para fornecer [...] atalhos, [...] e fórmulas patenteadas para aliviar os consumidores desse peso, ou pelo menos convencê-los de que o alívio cobiçado de fato chegou - por um momento." (BAUMAN, 2007, p. 142).

Bauman afirma que a internet oferece uma constante alteração de identidades em novos começos e nascimentos múltiplos. Fantasiar sem se expor faz parte da rede e experimentar novos 'eus', no espaço virtual pode consistir em assumir determinadas identidades sem medo de culpa ou punições. Algumas vezes, estes papéis seriam insustentáveis tanto fisicamente quanto socialmente off line, mas este jogo carnavalesco de identidades afasta o contato face a face em função das exigências que tal proximidade exige. A melhor alternativa ao invés do reconhecimento de uma identidade que levaria a um esforço longo e interminável, são os chamados blefes na rede, permitindo um substituto a sociabilização real, libertando do risco da decepção e do reconhecimento. Nesse processo o outro é um dado manipulável, um instrumento de autoconfirmação pessoal.

A sociedade de controle formulada por Deleuze apresenta a fluidez da sociedade de consumo, enquanto a sociedade de produtores apresenta a rigidez da sociedade disciplinar. Evidente que os conceitos não são iguais e que uma sociedade não se perfaz em substituição a outra. Em alguns momentos se superpõem, em outros se completam. Mas, é inegável que o ciberespaço apresenta uma formatação propicia a uma distribuição de poder que caminha de uma lógica disciplinar e produtora para uma fluida e consumista através de todo o campo social. Tal formatação tem sérias conseqüências no direito à privacidade, pois o controle panóptico de vigilância continua presente sob novas formas de rede e novos fluxos informacionais. 'O 'espaço estriado' das instituições da sociedade disciplinar dá lugar ao 'espaço liso' da sociedade de controle [...]. Enquanto a sociedade disciplinar forjava moldagens fixas, distintas, a sociedade de controle funciona por redes flexíveis moduláveis" (HARDT, 2000, p. 357).

A sociedade disciplinar era um espaço preponderantemente de corpos, onde se efetivou o trabalho manual. Em busca de equilíbrio entre 
produção e riqueza, procurou uma melhor produtividade e uma docilidade política própria, potencializando a dessacralização do tempo. Já a sociedade de controle surgida em meados do século XX redimensiona nosso conceito de espaço, pela desterritorialização constante, redimensionamento em novos fluxos e fracionamento entre as fronteiras do público e do privado, revendo os conceitos de nação, do território e das relações entre o homem e cidadão. Ela demarca novos itinerários que se direcionam em novos fluxos, e se localizam por meio de infovias, sem espaços demarcados, que acabam por orientar um fluxo produtivo que enfraquece as localidades físicas permeadas de poder e resistência. Tais instrumentos criam novos processos de sujeição, independente de limites fronteiriços e de permissões circunstanciais. A sociedade de controle trabalha com a perspectiva de que através dos mercados e as políticas transacionais haverá segurança para todos tendo como requisito apenas que o fluxo siga seu rumo, sem interrupção, numa velocidade que você terá que acompanhar ou ser abandonado, no intuito de atender o mercado e ser absorvido, a partir de um novo conceito do privado (PASSETTI, 2004, p. 151-160).

O fim do fora, ou a ausência gradual de distinção entre o dentro e o fora, na passagem da sociedade disciplinar para a sociedade de controle, tem importantes implicações para a forma de produção social da subjetividade. Uma das teses centrais mais comuns nas análises institucionais de Deleuze e Guattari, Foucault, Althusser e outros, é que a subjetividade não é originária, dada a priori, mas se forma pelo menos até certo ponto, no campo das forças sociais. (HARDT, 2000, p. 367).

A sociedade de controle não funciona mais por confinamento mais em uma comunicação contínua e instantânea. Não estamos abandonando as práticas das disciplinas, mas aprimorando-as. A educação passará a ter um caminho muito mais aberto, através do ensino a distância, mas com um aprendizado contínuo, onde o mercado regulará com um controle mais efetivo as suas diretrizes, direcionando a formação do operário-aluno ou do executivo-universitário (DELEUZE, 1990, p. 220). Além do mais, essa sociedade não abandonará as práticas de confinamento disciplinares, mas com outra roupagem poderá criar arcabouços virtuais que vigiará seus hábitos e formatará seu comportamento a partir de perfis de consumo.

A criação de subjetividade é um processo constante de 
engendramento e é substancialmente criada pela sociedade, a partir do funcionamento das principais instituições sociais. No decurso de uma vida nos deparamos com diversas instituições que moldam nosso sujeito, a escola, a família, a caserna, e em cada uma delas nos fechamos dentro dos seus muros, nos protegendo do lado de fora, mas sendo a nós impostos em cada fase sua característica disciplinar. Na passagem para a sociedade de controle, no contexto pós-moderno, as subjetividades são intensificadas em um processo não de oposição com a fase anterior, mas de intensificação. Passamos de espaços territorialmente definidos e fechados, a partir das disciplinas, para um espaço aberto, virtual, que perfaz todo o corpo social ilimitadamente. Com a derruba dos muros (que pode inclusive ser observada com a concretização física da derrubado do muro de Berlim, que simbolizou a mudança ideológica da dicotomia capitalismo-socialismo), não se pode mais distinguir o dentro do fora, com uma não definição do lugar da produção correspondendo a uma indeterminação das subjetividades que são produzidas, acarretando uma intensificação e generalização das formas disciplinares (HARDT, 2000, p. 369).

Hardt e Negri (2010, p. 11) ao analisarem a formação dessa nova sociedade de controle afirmam que se baseia na formação de um novo 'império'. A partir de um mercado global, de sucessivas trocas econômicas e culturais e o estabelecimento de circuitos locais de produção, surge uma nova estrutura de comando, que é a substância da política que governa o mundo. Surge um sentimento que esta nova era de globalização está se afastando dos controles políticos e que a soberania dos Estados-nação está em declínio e há quem acredite, que os canais institucionais de representação dos trabalhadores e cidadãos se fecham de maneira que o processo de contestação e influência a este sistema está cada vez mais fracionado. O fluxo de mercadorias e bens circulando livremente, com o advento do ciberespaço e da rede de informações on line, tem diminuído o papel de soberania dos Estados, até os mais importantes, e passado para as empresas transacionais, de serviços e tecnologia, um novo modelo de poder que independe de fronteiras e nações. $O$ declínio dessas potências em face da desterritorialização espacial, da informatização e pela impossibilidade de regulação dessa permuta econômica e social seria o indicativo da chegada desse novo império.

Neste caso a uma mudança no modo de produção capitalista ocasionado pela transformação da geografia em face das novas 
tecnologias informacionais e comunicacionais que são objetivadas e pautados por uma ótica consumista. No lugar da mão de obra industrial do modelo das sociedades disciplinares, temos a necessidade de uma mão de obra comunicativa, cooperativa e global. Essa pós-modernidade líquida da economia global carece de uma produção biopolítica, onde o econômico, o político e o cultural possam se sobrepor e se completar com a primazia do primeiro em toda a sua plenitude. O império não se estabelece fisicamente, nem tem semelhanças, a princípio, com os da China, das Américas ou romanos. Ele se caracteriza pela ausência de fronteiras e limites. Seu intuito é governar o mundo todo, com uma ordem que se apresente como uma forma de biopoder e assegure um regime sem fronteiras temporais, com seu conceito sempre "dedicado à paz - uma paz perpétua e universal fora da história" (HARDT; NEGRI, 2010, p. 13).

Quanto a analisamos a teoria da soberania, verificamos que o direito de vida e morte era um de seus elementos fundamentais. Era exercido de forma desequilibrada, pois somente o soberano tinha o direito de matar. No século XIX, surgiu um novo direito, que não vai apagá-lo, mas complementá-lo que é o direito de fazer viver e deixar morrer. Segundo Foucault esta nova tecnologia de poder, não disciplinar se dirige: "a multiplicidade dos homens, não na medida em que eles se resumem em corpos, mas na medida em que ela forma, ao contrário, uma massa global, afetada por processos de conjunto que são próprios da vida" (FOUCAULT, 2005, p. 289). Ela atinge não só o homem- corpo, mas, através de uma biopolítica, toda a espécie humana.

Enquanto teorias antigas do direito apenas conheciam a relação do indivíduo com o corpo social, constituído pelo contrato implícito ou voluntário em uma ótica disciplinar, essa nova tecnologia do poder tem um novo corpo múltiplo, com inúmeras cabeças, necessariamente mutável. A biopolítica lida com a população como: problema político, biológico e de poder. Ela vai se dirigir às estatísticas, previsões, medidas globais, não visando o indivíduo, mas o todo, e estabelecendo mecanismos reguladores naqueles fenômenos que se constituem globalmente. Ela visa à erradicação da doença, em uma medida higienizadora. Com isso, além do incentivo a criação de instituições, cria mecanismos sutis de controle, levantando dados coletivamente a fim de enumerar as incapacidades biológicas diversas e extrair poder e definir o campo de intervenção desse poder. Ela é um direito de fazer viver, de se intervir cada vez mais nos meandros da vida, intervindo para aumentá-la, 
para controlar as eventualidades, as deficiências, até a morte, que se define como a extremidade desse poder (FOUCAULT, 2005, p. 293/295).

Essa nova metodologia, com seus levantamentos estatísticos e a busca de uma higienização coletiva, permearia a sociedade de controle que se perfaz posteriormente, produzindo novas formas de poder e saber. A introdução de uma nova interação em rede com um efeito global e aglutinador criando uma ligação de indivíduos que buscam informação (o direito de fazer viver), mas, muitas vezes, sentem um imenso vazio (direito de deixar morrer) por privilegiar falsos padrões de consumo. Para atingi-los, os jovens são submetidos a uma profunda inadequação, através de uma eterna vigilância das redes sociais, que lhe exige um determinado comportamento, e se aproveita de uma catalogação e monitoração constante, a fim de constituir perfis que possam estabelecer seus padrões de consumo, ou servir para a alimentação de banco de dados para possíveis opções de empregos.

O modelo consumista de produção, a viabilidade de trocas comerciais sem controle por um estado soberano, e uma nova forma de poder global, advertiriam para a formação dessa entidade abstrata que os Negri e Hardt, auto-intitularam de Império.

Sua formação estaria ligada a uma forma paradigmática de biopoder e biopolítica, que seria adequado à globalização e as relações econômicas e sociais. Alguns teóricos afirmam que os Estados-nação capitalistas dominantes continuam a exercer o poder imperialista sobre as outras nações do globo e que o novo Império seria apenas uma nova formatação do antigo. Mas, podemos observar que os conflitos anteriores entre as potências foram substituídos pela idéia de um poder único, que se estrutura em uma noção comum de direito pós-colonial ou pósimperialista. As configurações jurídicas desse modelo são importantes, pois representariam as mudanças na construção da ordem e poder mundiais, bem como uma visão da tendência à regulamentação centralizada e unitária do novo mercado mundial, conforme as relações globais de poder. Estamos vivenciando uma transição da lei internacional tradicional, que era definida por tratados e contratos, para a constituição de um novo poder soberano supranacional, o qual se identifica os processos sociais totalizantes do império. Ela não se apresenta apenas no âmbito internacional, mas também nas relações do âmbito interno em cada país. Cada sistema jurídico soma um conjunto de valores específicos, sendo a ética o instrumento da materialidade, da fundamentação jurídica. Mas, a fim de universalizar o ético e o jurídico 
temos a impressão que "no Império há paz, no Império há garantia de justiça para todos. O conceito de Império é apresentado como um conceito global, sob a direção de um único maestro, um poder unitário que mantém a paz social e produz suas verdades éticas." (HARDT; NEGRI, 2010, p. 27-28).

O império a partir dessa dinâmica ética-política aponta duas tendências: a de uma nova ordem que permeia toda a civilização em um espaço ilimitado, universal e a apresentação de uma noção de direito atemporal, convocando o passado e o futuro para dentro de sua própria ordem ética, pregando o fim da história, apresentando-se como algo imprescindível, permanente e eterno (KANAAN, online).

Segundo Fukuyama a partir da crise do socialismo e o avança do modelo capitalista como melhor caminho aos países civilizados, estaríamos chegando ao último estágio ao avanço econômico mundial. A partir de uma sociedade tecnológica que pudesse suprir as necessidades humanas teríamos todas as questões resolvidas, seria o 'fim da história'. As antinomias entre comunismo e democracia estariam conclusos, com a prevalência do segundo que abre espaço para satisfação do desejo e reconhecimento individual. Limitar o poder de consumo e o crescimento igualitário geraria frustração e buscariam novas opções de governo que atendessem estes padrões. Seria inexorável a passagem para uma economia liberal com o caminho através da globalização, sem nenhuma ideologia que estivesse apta a enfrentá-la. "A vida na democracia liberal é potencialmente o caminho para a grande abundância material" (FUKUYAMA, 1992, p. 97).

O conceito do novo império não se conduz com a abordagem de Fukuyama. É evidente que observando a histórica recente com a perda de poder político cada vez maior dos Estados Unidos, podemos ponderar que esse modo de produção, que está condenado a produzir e reproduzir permanentemente tal relação social, não conduz necessariamente à liberdade. Mas, conduz a uma nova ordem, que analisaremos a seguir.

Há duas noções de direitos que permeiam a formação dessa nova civilização universal, que já existiam na idade média e com o Renascimento foram separados. O primeiro surgiu no pensamento político europeu que buscava a paz eterna através de uma conceituação do direito internacional, que já era prometida desde o Império Romano, que pretendia através de um mecanismo de tratados constituir uma ordem internacional entre os Estados soberanos. O segundo caso, através de Kant e Bernardin de Saint-Pierre seria a concepção da idéia da busca do 
ideal da razão, de maneira a unir o direito a eticidade, em uma visão transcendental do sistema jurídico. Toda a modernidade européia e perpassada pelo debate dessas duas ideologias: a ideologia liberal que visava o "concerto pacífico de forças jurídicas e sua substituição no mercado; e a ideologia socialista que se concentra na unidade internacional mediante a organização de lutas e a substituição de direito." (HARDT; NEGRI, 2010, p. 27/29).

Na pós-modernidade a noção de direito pode se tornar uma só, em função da nova contextualização do Império. Esse novo paradigma, com a construção centralizada de normas e legitimidade cada vez maior, tem se espalhado pelo espaço mundial a partir de um determinado modelo econômico. Ele se opõe, diferentemente das outras tentativas de uma ordem internacional, a partir de uma totalidade sistêmica, rompendo com as dialéticas anteriores, impondo uma autoridade suprema que possa efetivar um processo de integração e resolver todos os conflitos, todas as crises e desavenças. Seus movimentos são estabelecidos dentro do próprio sistema e visam um processo de constitucionalização da ordem mundial, a fim de exercer uma norma efetiva, com poder coercitivo. Daí, segue a utopia Kelseniana para sistematização de uma norma fundamental, buscando elementos na formação desse sistema. O império é convocado a nascer e constituído para resolver todos os conflitos, ele "se forma e suas intervenções tornam-se juridicamente legitimadas somente quando já está inserido na cadeia de consensos internacionais destinados a resolver conflitos existentes.” (HARDT; NEGRI, 2010, p. $33)$.

Ainda, que já se existisse um modelo antigo que visava uma forma global de autoridade, é necessário ir além desses parâmetros na formatação do novo paradigma. A formação do império acrescenta várias escolas, do positivismo retira o forte poder central normativo, do direito natural à busca pela paz e equilíbrio universal, do contratualismo a tentativa de alcançar um consenso, do realismo traz às metodologias geradoras das instituições adequadas as novas dimensões de autoridade, do formalismo o apoio lógico a sistematização funcional, acentuando o totalitarismo do processo. Como abarcar um modelo jurídico supranacional com todas estas características? Os principais pontos seriam a normatividade, a sanção e a repressão, que se manifestariam pelo direito de intervenção e principalmente pelo poder de sanção. A formação desse novo direito estaria ligada a um poder de polícia supranacional (HARDT; NEGRI, 2010, p. 33-35). 
Esse novo direito intervencional teria como premissa a busca da justiça e da paz? Haveria um processo de constituição de uma ordem planetária, com uma consolidação de uma nova máquina administrativa e novas hierarquias de comando global? Para esse formato é necessário um novo aparelho jurídico com um direito e uma justiça supranacional?

Esta nova moldura nos obriga a confrontar uma série de explosivas aporias, porque neste novo mundo jurídico e institucional em formação nossas idéias e práticas de justiça e nossos modos de esperança são questionados. [...] $\mathrm{O}$ caráter nacional de valores, os abrigos atrás dos quais eles apresentavam sua substância moral, os limites que protegem contra a exterioridade invasora - tudo isso desaparece. Somos todos obrigados a confrontar questões absolutas e alternativas radicais. No Império, a ética, a moralidade e a justiça ganham novas dimensões. (HARDT; NEGRI, 2010, p. 37).

O ciberespaço apresenta uma formatação propicia para formação desse poder unificador, sua ligação em rede global sem um ponto central, com uma interação de idéias e a sensação de fluxo constante, proporciona a noção de totalidade e de horizontalização de costumes e de normas. Desse modo, uma inovadora subjetividade de internautas e de pessoas interligadas está surgindo em uma nova base ontológica. Mas, em contrapartida, há uma exigência social da participação nessa nova ordem a fim de integrar as redes sociais e estar conectado on line em busca de novas informações. Essa eterna busca de completude e de finitude pode chegar ao ponto que aquilo que não estiver no buscador google não exista no mundo real, ou que as memórias ou a história sejam reformatadas, como nos inimigos do estado do universo orwelliano. Estas pessoas desapareciam não só fisicamente, mas também no imaginário popular, elas nunca existiram, suas imagens, suas informações, tudo era deletado. era uma sociedade sem biografia, a história era constantemente reescrita, como uma página de hipertexto. $\mathrm{O}$ próprio objetivo do site buscador é de ser um enciclopedista universal, ou seja, poder armazenar toda a informação do mundo (em suas informações corporativas afirma-se que a missão do google é organizar as informações do mundo e torná-las mundialmente acessíveis e úteis). $\mathrm{O}$ seu famoso lema 'not be evil' foi originalmente sugerido pelos funcionários Paul Buchheit e Amit Patel em uma reunião e colocado como número seis de sua filosofia corporativa (possível fazer dinheiro 
sem fazer o mal). É um indicativo da formação do império através da busca de uma eticidade e paz universal, reconstruindo o passado com um futuro único, a partir da catalogação populacional através do exame e das pesquisas, a fim de controlar os indivíduos em suas nuances, utilizando a tecnologia do biopoder para alcançar estes resultados. O poder é tomado de uma forma sutil e sempre em um ambiente de liberdade, ele "é uma estrutura de ações; ele induz, incita, seduz, facilita ou dificulta; ao extremo, ele constrange ou, entretanto, é sempre um modo de agir ou ser capaz de ações. um conjunto de ações sobre outras ações" (FOUCAULT, 1995 apud MAIA 1995, p. 90).

Seu propósito de catalogar, elaborar perfis, estatísticas e de dominar as informações dos indivíduos de maneira a construir uma nova identidade, mantendo um conjunto de normas éticas que vise o bem maior da humanidade, sem sombra de dúvida, é o maior exemplo do uso do biopoder para formação de uma sociedade de controle a partir de novas formas de exame. "Ter-se-ia por um lado, uma espécie de corpo global, molar, o corpo da população, junto com toda uma série de discursos que lhe concernem e, então, por outro lado e abaixo, os pequenos corpos, dóceis, corpos individuais, os micro corpos da disciplina." (FOUCAULT apud MAIA 1995, p. 94).

Foucault nos preparou para entender a formação desse novo Império ao analisar os mecanismos de inclusão ou exclusão por meio das instituições (prisão, fábrica, asilo, hospital, a escola) que perfazem o tecido social. O poder disciplinar foi atuante em toda a primeira fase de acumulação capitalista. Neste ponto, se privilegia o controle do corpo, em função de uma vigilância singular, específica. $\mathrm{Na}$ passagem da modernidade para pós-modernidade com o estabelecimento das sociedades de controle o exame se torna mais ‘democrático' atingindo um maior número populacional, de maneira a aumentar sua imanência ao corpo social. O poder se exerce através dos computadores, como interface cerebral interligado em redes flexíveis e flutuantes com outros indivíduos, intensificando os aparelhos de normalização e de disciplinariedade (HARDT; NEGRI, 2010, p. 42).

A introdução do conceito de biopoder basilar nas sociedades de controle se percebe com dois níveis de exercício de poder (MAIA, 1995, p. 94): o primeiro com a influência das disciplinas que atua no treinamento do corpo, em uma vigilância permanente e constante, controlando o tempo e a distribuição espacial dos indivíduos, não sobre o resultado de uma determinada ação, mas sobre seu resultado. Visa "não 
unicamente ao aumento de suas habilidades, nem tampouco aprofundar sua sujeição, mas a formação de uma relação que no mesmo mecanismo o torna tanto mais obediente quanto mais útil." (FOUCAULT, 1977, p.127), o segundo atua na população, nas suas leis e regularidades, tendo se formado na metade do século XVII e "centrou-se no corpo-espécie, no corpo transpassado pela mecânica do ser vivo e como suporte dos processos biológicos [...], tais processos são assumidos mediante toda uma série de intervenções e controles reguladores: uma biopolítica da população" (FOUCAULT, 1979, p. 131).

Essa nova tecnologia não vem substituir as disciplinas, o biopoder se integra com ela, passando de um controle individual para um populacional, sabendo-se que os instrumentos de coerção e exame também são usados na sociedade de controle, só que de maneira global e com muito maior acuidade, tendo em vista os métodos informacionais que proporcionam uma pesquisa muito maior com a possibilidade da formação de perfis mais completos.

Esse poder tem como função envolver a vida totalmente e administrá-la. Na sociedade disciplinar a utilização das técnicas do biopoder era parcial e sua realização era de maneira hermética, fechada e geométrica. Ademais, a introdução dos indivíduos em instituições não conseguiu êxito utilizando a socialização produtiva e as técnicas de vigilância, objetivando captar as suas consciências e seus corpos. Houve uma relativa estabilidade na invasão disciplinar do coator com a resistência do coagido. Mas, o controle biopolítico, abrangendo todo corpo social através das virtualidades desse poder, acaba funcionando como um só corpo em seus processos de desenvolvimento. Ao considerar a passagem da sociedade disciplinar para de controle no enfoque foucaulniano, a subordinação real vai além da dimensão econômica ou social abarcando o próprio 'bios' social, desfazendo a imagem totalitária do desenvolvimento capitalista.

Quando o conceito de direito aparece na globalização, se revela como capaz de tratar todos os povos em um conjunto único, com apenas a exigência de uma tecnologia coercitiva adequada, que se apresenta através dos instrumentos disciplinares. Para a sociedade capitalista o controle pela biopolítica era feito não só ideologicamente, mas através do somático, do físico. Foucault leva a discussão do problema da reprodução social para além dos termos econômicos, mas também em termos culturais, físicos e subjetivos. Gattari apresenta esta produção do ser social conectada com o funcionamento dos computadores e produzindo a 
realidade juntamente com os sujeitos e objetos que o constituem.

As máquinas tecnológicas informacionais "atuam no núcleo da subjetividade humana, não apenas no seio das suas memórias, da sua inteligência, mas também da sua sensibilidade, dos seus afetos, dos seus fantasmas inconscientes." (GUATTARI,1992, p. 14). Essa produção maquínica depende de sua articulação com os detentores coletivos de enunciação. Daí a importância na análise da distribuição do biopoder e de como se reunir às informações captadas e o propósito para seu uso, a partir do uso da tecnologia. As recentes transformações no regime do trabalho no mundo capitalista têm transformado a força de trabalho dos operários, cada vez mais, em uma formatação imaterial. Esse processo reinserido no contexto biopolítico tem apresentado não só uma forma de poder pautada na linguagem e comunicação, mais também em aspectos afetivos, atuando principalmente no coletivo, pois seu alvo se dá em uma multidão de corpos que procuram uma relação (HARDT; NEGRI, 2010, p. 48-49).

\section{O PODER DA MULTIDÃO E A INTELIGÊNCIA COLETIVA NO CIBERESPAÇO}

Conforme já exposto, estamos na formação de uma nova perspectiva de constituição jurídica supranacional, as organizações da ONU, juntamente com as grandes agências transacionais de finanças e comércio como o FMI (Fundo Monetário Internacional), o OMC (a organização mundial do comércio) são consideradas dentro da dinâmica da produção biopolítica mundial. Essas grandes corporações constroem biopoliticamente uma nova reestruturação dos territórios globais. É evidente que tal papel se dá em função da nova realidade do capitalismo. Não há mais um centro de comando absoluto, mas a articulação de uma influência em territórios e populações através do fluxo de mercadorias, de dinheiro e pessoas que põe todo o sistema em movimento. Esse novo sistema hierarquiza os setores mundiais de produção dirigindo novas manobras financeiras e monetárias determinando uma nova geografia desterritorializada.

O meio em que se desenvolve esta produção biopolítica é a linguagem, através principalmente das indústrias de comunicação, e atualmente, das novas tecnologias informacionais. Esses meios organizam o movimento de globalização através da estruturação e interconexão em redes. A comunicação midiática se impõe como nova 
estrutura de poder no espaço global. Constrói novos tecidos sociais, e desenvolve na pós-modernidade uma nova formatação comunicativa, pretendendo inclusive um projeto de cidadania universal a partir do desenvolvendo de novas subjetividades, e de novas formas de controle. Essa manifestação desse poder fluídico se dá de modo virtual, e de uma nova forma de soberania. Ele aparece "na forma de uma máquina de altíssima tecnologia: é virtual, construída para controlar o evento marginal, e organizada para dominar e, quando necessário, intervir nas avarias do sistema [...], [é] uma nova máquina econômica-industrialcomunicativa - em resumo, uma máquina biopolítica globalizada" (HARDT; NEGRI, 2010, p. 58-59).

A estrutura formadora dos Estados-nação soberanos tem uma formatação ultrapassada. O novo modelo de autoridade tem uma racionalidade que não traz uma tradição jurídica, mas, através de mecanismos de gerenciamento industrial e dos usos políticos de tecnologia se manifesta. Através de um modelo econômico próprio este novo império abstrato se manifesta globalmente, com "diferentes redes de fluxo e obstáculos, nos quais o momento ou a perspectiva local dá prioridade a barreiras ou fronteiras de reterritorialização, e o momento global privilegia a mobilidade de fluxos desterritorializantes" (HARDT; NEGRI, 2010, p. 64).

Não há o que se acentuar a diferenciação global e local, a nova coletivização da informação acaba com essa dicotomia, informando globalmente e respeitando aspectos locais. As subjetividades formadas a partir desses eventos muitas vezes perde seu controle central e fortalece através do nomadismo universal, da mistura geral e da miscigenação de indivíduos e populações a formação de um trabalho ativo, com poderosas singularidades.

A base antológica para a formação de uma configuração jurídica transnacional, nesse contexto, se constitui de uma configuração abstrata e vazia, com a privação do ser e da sua produção através de um controle sobre a sociedade e a vida.

Há uma indeterminação das subjetividades produzidas neste modelo. E existe uma tendência em sua generalização ao redor do mundo. Enquanto no velho modelo havia uma exportação das formas institucionais dos países desenvolvidos para os subdesenvolvidos, no atual se exporta a própria crise, inerente ao sistema como um todos. "A estrutura institucional do Império é como um programa de software que carrega um vírus, de modo que está continuamente regulando e 
corrompendo as formas institucionais à sua volta. A sociedade imperial de controle é tendencialmente em toda parte a ordem do dia" (HARDT; NEGRI, 2010, p. 217).

Houve uma mudança em relação entre o capital e o Estado no século XX. As grandes empresas transacionais ultrapassam as esferas dos Estados em autoridade e jurisdição, perdendo a eficácia do modelo de soberania como nós o conhecemos. Hoje o consenso não é dado na esfera política, mas na esfera do poder econômico, através do equilíbrio das balanças comerciais e da especulação sobre o valor das moedas. Governo e política fazem parte de um sistema de comando transnacional. A noção de autonomia do político dá lugar a um controle articulado mediante novas funções internacionais. As funções constitucionais se deslocaram para outro patamar. Ela pode ser concebida na forma de uma rede de comunicações rizomática e universal, sendo em si mesma um não lugar real e apropriado.

Esses elementos constitucionais globais estão distribuídos num amplo espectro de corpos (em Estados-nação, em associações de Estados-nação, e em organizações internacionais de todos os tipos); eles estão divididos por função e conteúdo (organismos políticos, monetários, de saúde e educacionais); e são atravessados por uma variedade de atividades produtivas. (HARDT; NEGRI, 2010, p. 330).

Essas configurações se apresentam em vários níveis. Hegemonicamente está os Estados unidos, uma superpotência que se impõe a partir do fim da Guerra Fria. Logo abaixo temos um grupo de Estados-nação que são representados por uma série de organismos internacionais, como G7, o clube de Londres, de Paris e Davos. Um conjunto heterogêneo que estabelece um poder biopolítico global. A segunda camada está às redes de empresas capitalistas transacionais, proporcionando a distribuição global de capitais, pessoas tecnologias, se estabelecendo em redes de comunicação garantindo e abastecendo os mercados dos grupos da primeira camada. Juntamente com estas empresas se situam os Estados-nação que atuam localmente a partir delas, mediando politicamente suas ações e redistribuindo renda e fornecendo lucros de acordo com suas necessidades biopolíticas territoriais. A última camada e a mais importante são os grupos que representam o povo, e seus interesses na estrutura global de poder, a que 
Hardt e Negri chamam de 'multidão' (HARDT; NEGRI, 2010, p. 331332 ).

Várias organizações representam esta entidade abstrata, a organizações de direitos humanos (Anistia Internacional) e agências de socorro (médicos sem fronteiras), entre outras, fundamentando-se em uma moral universal.

A sociedade civil durante determinado período histórico (visão hegeliana da dialética entre a pluralidade de indivíduos econômicos e o Estado) conseguiu mediar às forças de capital e da soberania moderna. Ela canalizou forças sociais e econômicas a fim de irrigar o espaço social imanente. Mas, na nossa época elas não conseguem cumprir este papel em toda sua totalidade. Há um declínio na relação capital trabalho, com o enfraquecimento dos sindicatos e da representação coletiva dos trabalhadores. A passagem da sociedade disciplinar para a de controle estão fazendo com que antigas instituições (escola, hospital e a fábrica) sofram uma crise sem precedentes constituindo uma verticalidade e transcendência no plano social. Esta ocorre não por um Leviatã hobbesiano vindo do alto, mas a partir de uma vontade imanente vindo de nossa própria subjetividade. Quando se observa o panóptico foucaltiano o exercício do poder não se dá como um soberano em relação aos seus súditos, mas através de um espaço e técnicas disciplinares próprias. Ainda que atualmente não aja mais uma localidade própria para esse exercício, sendo as redes virtuais um 'não lugar', o definhamento das instituições não retira o caráter de controle imanente ao exercício da disciplina. Ocorre dentro das subjetividades uma lógica disciplinar que obriga à autodisciplina dos sujeitos e delineiam a nova sociedade de controle, em função das modernas instituições sociais, que se apresentam com objetivo de produzir identidades sociais mais móveis, flexíveis, híbridas e moduladas (HARDT; NEGRI, 2010, p. 350-351).

Organizar essa nova formatação entre os extremos de riqueza e pobreza é o grande desafio da sociedade de controle, a fim de garantir a administração do espaço social. Estamos com um acentuado declínio do espaço público, devido às novas redes de computação que tornaram possíveis a interligação de forças de trabalho em tempo real e também a uma competitividade entre os trabalhadores que ultrapassa as fronteiras territoriais. Com a imposição de uma flexibilidade temporal e mobilidade espacial o capital enfraqueceu as forças de trabalho em face de suas estruturas rígidas salariais, culturais e geográficas. Tais ações têm gerado uma desregulamentação excessiva e aumentado à exploração em 
decorrência das novas segmentações setoriais criadas. O medo do empregado está sempre presente tanto da pobreza como da ansiedade quanto ao futuro. O novo mundo digital e interligado, muitas vezes, é um mundo que se alimenta do medo. Como enfrentá-lo? Esse modelo passa por um controle biopolítico que tem por base a multidão produtiva, que deve, sob todas as formas, ser normalizada e governada em toda a sua autonomia, através de permutas, cultura e linhas internacionais. "Em sua autonomia desterritorializada, entretanto, essa existência biopolítica da multidão tem o potencial de ser transformada numa massa autônoma de produtividade inteligente, num poder democrático absoluto" (HARDT; NEGRI, 2010, p. 366).

A construção da comunidade está intimamente ligada à noção de trabalho como poder comum de agir. Seu poder virtual está na autovalorização, constituindo uma comunhão expansiva. É um poder material que é constituído por mecanismos ontológicos que se manifestam de baixo para cima, que é comum a todos e se manifesta além da medida, que plantado através de uma virtualidade procura ser real. "A expansividade unilateral do poder demonstra a base ontológica da transvalorização, isto é, sua capacidade não apenas de destruir os valores que descem do reino transcendental da medida, mas também de criar novos valores" (HARDT; NEGRI, 2010, p. 381).

$\mathrm{O}$ poder virtual atua na potencialidade da multidão. Ele se opõe à força opressiva do 'Império', da manifestação do capital transacional opressivo e formador de um modelo de consumo que retira a vitalidade e identidade das pessoas. É necessário a formação de uma cidadania global, que se enfrente a "a luta a pertencer a uma nação, uma identidade, a um povo, e portanto a deserção da soberania e dos limites que ela impõe a subjetividade" (HARDT; NEGRI, 2010, p. 384). O processo de circulação informática caminha para a virtualização da multidão, na medida que através da circulação das informações visa criar uma ética contra o modelo vigente. Esta ruptura através do circular e da mistura biopolítica se concentra nas atividades de produção, autovalorização e liberdade.

[...] autovalorização do humano (o direito igual de cidadania para todos na esfera inteira do mercado mundial); como cooperação (o direito de comunicar-se, construir línguas e controlar redes de comunicação); e como poder político, ou melhor dizendo, como a constituição de uma sociedade na qual a base do poder é definida pela expressão 
das necessidades de todos. Esta é a organização do operário social e do trabalho imaterial, uma organização do poder produtivo e político como unidade biopolítica administrada pela multidão, organizada pela multidão, dirigida pela multidão - democracia absoluta em ação. (HARDT; NEGRI, 2010, p. 433-434).

As novas formas de trabalho e sua característica imaterial criam novas formas de afetividade e de oposição ao biopoder que submete a multidão à sociedade do capital. Seu valor é cada vez mais, realizado de modo singular, refinado e interativo, alterando o processo de reprodução social. O modo de compreensão da economia política está alterado, a vida influencia a produção, através da inteligência coletiva, pelo intelecto geral elas são renovadas pelos afetos, paixões subjetivas e se redefinem nas relações sociais.

Com a força coletiva da multidão teremos a partir de uma interação humana-máquina uma nova relação de poder. Há uma oportunidade única de se transferir os instrumentos materiais de produção a partir da inteligência coletiva e formar novas virtualidades em um processo metamorfo de possibilidades. Estamos nos afastando das velhas tradições metafísicas para alcançar um novo telos materialista, a partir de singularidades próprias e do casamento entre o virtual e o possível em uma inovação como máquina revolucionária (HARDT; NEGRI, 2010, p. 391).

Ultrapassar a ilusão metafísica da insuperabilidade e eternidade do mercado capitalista de produção é uma das dificuldades a ser ultrapassada para se constituir, em sua plenitude, o exercício do poder da multidão. Tão pouco, não se deve seduzir pela retórica mística que a única solução seria uma alternativa anarquista, radical para combatê-lo. Estas opções não atingem a ordem principal da biopolítica que é a produtividade. Os corpos da multidão são enriquecidos com poder intelectual e cooperativo, de maneira híbrida. A solução para crise está nos processos de produção de subjetividade através da virtualidade biopolítica. Este movimento coletivo de essências singulares é o verdadeiro motor gerador dessa nova sociedade. É o momento de se abandonar à ontologia transcendente para uma biosfera generativa e produtiva. "Dessa forma chegamos a um limite da virtualidade da subordinação real da sociedade produtiva ao capital - mas justamente nesse limite a possibilidade de geração e a força coletiva do desejo são reveladas em todo o seu poder" (HARDT; NEGRI, 2010, p. 411). 
O século XX avançou e transformou o movimento de classes. A metodologia dominante não conseguiu propor as condições de uma subjetividade política que oferecesse uma nova realidade a partir da globalização das relações sociais e econômicas. A multidão a partir do trabalho oferece esta alternativa. Ela produz e reproduz o mundo da vida, e a partir da cooperação consegue alterar a ilusão ideológica que o homem é permutável em função dos interesses consumistas. Ao contrapor o mercado, através de suas próprias singulares biopolíticas produtivas, quer controlar ser próprio destino e formar uma nova cidade. O ciberespaço contribui para esta configuração, pois aparece como um movimento espacial contínuo de pessoas e informação que ultrapassa fronteiras constituindo um lugar ilimitado.

Cada vez menos os passaportes e documentos legais serão capazes de regular nossos movimentos através das fronteiras. Uma nova geografia é estabelecida pela multidão à medida que os fluxos produtivos de corpos definem novos rios e portos. As cidades da terra se tornarão de imediato grandes depósitos de humanidade cooperativa e locomotivas para a circulação, residências temporárias e redes de distribuição em massa de ativos seres humanos. (HARDT; NEGRI, 2010, p. 421).

Essa nova distribuição de espaços fluídica abre novos caminhos e novas formas de riqueza. Os trabalhadores cada vez mais migram em uma interconexão contínua em busca de melhores condições de vida. Esse poder de interação reafirma uma autonomia própria e cria uma resistência às forças do nacionalismo e do fundamentalismo. Como organizar politicamente esta entidade abstrata que é a multidão? Nesse primeiro momento é difícil prever, mas sua força política pode ser desenvolvida, a princípio, a partir de uma cidadania global. Nesse contexto há necessidade que o trabalhador, independente de sua origem, seja reconhecido seu direito de cidadania. A mão de obra irregular do México ou na Europa deve ter os mesmos direitos que os cidadãos de seus respectivos países, tendo em vista que contribuem para o desenvolvimento local. A análise vai além e aponta a necessidade do direito das massas terem controle de seu próprio movimento, se apresentando como uma premissa utópica, mas em um mundo globalizado os trabalhadores devem poder se deslocar conforme seus interesses e o do próprio capital, sem limitações discriminatórias. 
Por isso a demanda política exige que o fato da produção capitalista seja reconhecido juridicamente e que todos os trabalhadores recebam plenos direitos de cidadania. Com efeito, essa demanda política insiste na pós-modernidade do princípio constitucional fundamentalmente moderno que vincula direito e trabalho, e por isso contempla com a cidadania o trabalhador que cria o capital. (HARDT; NEGRl, 2010, p. 424, grifo nosso).

Nesse novo mundo é cada vez mais difícil distinguir entre o trabalho material, imaterial, intelectual ou físico, o proletariado aparece com um novo poder. Através da linguagem e comunicação forma a estrutura corporativa necessária para a sua libertação. Através da sua ligação maquinal em rede com novos usos e atuando como agente autônomo da produção proporciona uma criação coletiva da história. Essas ferramentas biopolíticas produzem regimes específicos de produção, em um novo uso das máquinas e do capital variável. Mas, como seria a formação de um 'telos' para esse conceito de 'multidão nascente'? A comunicação seria o primeiro aspecto a ser considerado, a partir de um sistema informacional que atuaria como catalisador de um novo uso tecnológico, onde a detenção dos meios de produção poderiam ser redimensionados. Esse hibridismo máquina-homem seria essencial para formação de um novo poder.

A composição das intensidades territorializantes se encarna em máquinas abstratas. É preciso considerar que existe uma essência maquínica que irá encarnar em uma máquina técnica, mas igualmente no meio social, cognitivo, ligado a essa máquina — os conjuntos sociais são também máquinas, o corpo é uma máquina, há máquinas científicas, teóricas, informacionais. (GUATTARI, 1992, p. 51).

Além desse hibridismo que sustenta a inteligência coletiva e se manifesta na formação da multidão temos uma nova subjetividade do trabalho ativo se revelando. A luta dessa nova linguagem tecnológica, que nada mais é que o meio coletivo de constituição de uma nova realidade se manifesta no poder da vida e da organização política. Nessa formação torna-se possível através da solidariedade e da igualdade uma nova formatação de um poder constituinte. A máquina não é usada apenas na produção, mas na integração das mentes e corpos da multidão. Daí surge o direito a reapropriação dos meios de produção, na tomada de 
controle da informação, comunicação e afetos (HARDT; NEGRI, 2010, p. 424).

Nesse aspecto se enfatiza incomensurabilidade do tempo e do valor, sendo difícil separar lazer e trabalho. Há a necessidade de se pensar novas formas de remuneração e de renda social, privilegiando os aspectos coletivos. Em um processo histórico da classe trabalhadora tivemos uma primeira fase de produção industrial, a partir dos regimes fordistas e tayloristas que tinha o trabalhador organizado hierarquicamente na produção industrial, em uma segunda fase houve uma extensão do poder da classe trabalhadora nos mecanismos de reprodução social, com a legitimação dos sindicatos e a construção de um Estado de bem estar social, imposto por um desenvolvimento capitalista. E na atualidade, com um processo pós-fordiano nos apresentamos com a valorização do trabalho imaterial e com a figura do operário social. $\mathrm{O}$ poder constituinte do trabalho que é construído nessa caracterização se apresenta como a uma unidade biopolítica da multidão.

As ferramentas de produção tendem a ser recompostas em subjetividade coletiva e na inteligência e no afeto coletivos dos operários; a capacidade empresarial tende a ser organizada pela cooperação de indivíduos em intelecto geral. A organização da multidão como sujeito político, como posse, começa portando a aparecer na cena mundial. A multidão é auto-organização biopolítica. (HARDT; NEGRI, 2010, p. 434).

\section{CONSIDERAÇÕES FINAIS}

A formação das sociedades disciplinares cria uma relação que transforma o homem em um corpo submisso, com docilidade e obediência. Esse olhar da inspeção controla a experiência humana, e se faz circular em uma rede de relações, que se pode identificar uma hierarquia de saber ou capacidades, criando máquinas de ensinar, de vigiar, de hierarquizar e de recompensar, em um sistema hermético, separando as pessoas, segundo seu temperamento, aplicação, limpeza e fortuna. O poder disciplinar está em toda a parte. Sua visibilidade e transparência controlam continuamente a todos, pois funciona permanentemente e em grande parte em silêncio. A grande idealização dessa metodologia foi criada por Benthan em 1785, o panóptico, um aparelho de vigilância, que opera como uma engrenagem importante do poder disciplinar, atuando de modo múltiplo, automático e anônimo, em uma 
rede de relações de alto a baixo; e de baixo para cima, inclusive lateralmente, onde todos são vigiados, os fiscais e os fiscalizados. É a utopia orweliana onde o olhar central tudo vê e todos vêem, mas não pode ser visto.

A visibilidade tem função primordial na arquitetura do seu sistema, sem uma coletividade definida, suas individualidades se fundem, induzindo no detento um estado permanente de observação que garante um funcionamento automático do poder. É um espetáculo, um verdadeiro teatro do castigo, como se fosse um circo romano, inclusive com acesso a um grande número de pessoas a esta vista macabra.

Passamos de uma sociedade de soberania, onde o rei exercia o poder através de uma vigilância externa e com modelagem fixa para uma sociedade disciplinar, na qual as instituições têm maior internalização, através de lugares fechados e regulados. Com as mudanças tecnológicas nos últimos anos caminhamos para o desenvolvimento de novas formas de controle, que através de um mundo globalizado cria salários, empregos e profissões flutuantes, se renovando continuamente, se apresentando de modo fluídico em uma nova sociedade em que tudo é monitorado e vigiado, não mais pelo exame físico, mas virtual.

Nesta passagem da sociedade disciplinar para a sociedade de controle não existe conflito, mas uma continuação da mesma sistemática, com outros instrumentos. Na pós-modernidade há uma desconstrução das fronteiras do Estado-nação, transformando a organização social como nós a conhecíamos. A cultura consumista é o fator significante dessa mudança, essa nova sociedade de consumidores reforça a escolha de um estilo de vida que suas compras traduzem em uma ascensão dentro da pirâmide social ou seja, você também se transforma em uma mercadoria. Esta sociedade do espetáculo é um lugar virtual que através dos perfis de usuários conectados, levantados pelos sites de busca, propicia uma categorização dos consumidores com objetivo de otimizar o lucro.

Essa sociedade de controle não funciona em sistemas herméticos, mas em uma comunicação contínua e instantânea que não abandona as práticas de confinamento disciplinares, mas cria novas alternativas virtuais que vigiará os hábitos dos consumidores e formatará seu comportamento a partir de perfis específicos.

$\mathrm{Na}$ formação dessa nova sociedade de controle a partir de sucessivas trocas econômicas e culturais em um mercado global e o fluxo de mercadorias e bens circulando livremente, com o advento do ciberespaço e da rede de informações on line, cria um novo modelo de poder que governa o mundo. Esta nova era de globalização está se afastando dos controles políticos e do 
exercício do poder dos Estados-nação, em face da desterritorialização espacial, da informatização e pela impossibilidade de regulação dessa permuta econômica e social no ciberespaço. Esta formatação exige uma mão de obra comunicativa, cooperativa e global. Essa pós-modernidade líquida da economia global carece de uma produção biopolítica que se caracteriza pela ausência de fronteiras e limites. Seu intuito é governar o mundo todo, com uma ordem que se apresente como uma forma de biopoder e assegure um regime sem fronteiras temporais, com seu conceito sempre "dedicado à paz - uma paz perpétua e universal fora da história".

Na pós-modernidade a noção de direito busca se tornar unitário, em função desse novo paradigma. A partir de uma totalidade sistêmica, rompe com as antigas tradições legais e tenta impor uma autoridade suprema, em um processo de constitucionalização da ordem mundial, baseado em uma ótica de mercado intrusiva e que privilegia a otimização de lucro em detrimento de direitos individuais, como a própria privacidade. Esta nova ordem permeia toda a civilização em um espaço ilimitado, universal com a apresentação de uma noção de direito atemporal, pregando o fim da história, sem dicotomias, apresentando-se de maneira eterna e permanente. Estamos na formação de uma nova perspectiva de constituição jurídica supranacional. Não há mais um centro de comando absoluto, mas a articulação de uma influência em territórios e populações através do fluxo de mercadorias, de dinheiro e pessoas, ocorrendo uma hierarquização dos setores, determinando uma nova geografia desterritorializada. Ela não se apresenta apenas no âmbito internacional, mas também nas relações do âmbito interno em cada país, sendo apresentada como solução para universalização do ético e do político, em uma forma de manifestação do biopoder e da biopolítica que seria adequado as relações econômicas e sociais.

A formação de uma configuração jurídica transnacional através de um controle sobre a sociedade e a vida se dá a partir de vários grupos, temos o G7, o clube de Londres, de Paris e Davos e as empresas capitalistas transacionais. Mas, o mais importante dessa estrutura global de poder é o grupo nomeado por 'multidão'. Uma entidade que em sua autonomia, cria um verdadeiro poder democrático e renovador. $\mathrm{O}$ poder virtual é o grande catalisador da sua potencialidade. Ela se opõe ao capital transacional e ao modelo de consumo que retira a vitalidade e identidade das pessoas, é o grande formador de uma cidadania global, que através da circulação das informações visa criar uma ética contra o modelo vigente, se concentrando nas atividades de produção, autovalorização e liberdade. As novas formas de trabalho imaterial é uma das fontes formadoras desse novo biopoder que 
transforma o processo de reprodução social. Influência a produção com sua interação humano-máquina em uma nova relação de saber transferindo os instrumentos materiais de produção a partir da inteligência coletiva e formando novas virtualidades conseguindo alterar a ilusão ideológica que o homem é permutável em função dos interesses consumistas.

Nesse contexto se observa uma maior mutação de inteligências coletivas, a partir da separação das atividades e opacidade dos processos sociais. Ela é o principal motor da cibercultura, com uma convergência de recursos, projetos e competências e em cooperação flexível e transversal, conseguindo distribuir os centros de decisão, opondo-se a compartimentalizações e minimizando os efeitos de exclusão dos indivíduos por seus grupos, resultando no aceleramento do movimento tecno-social. O ciberespaço contribui como um instrumento de navegação não hierárquica de navegação de saberes que cria um coletivo diferenciado, a partir do contínuo compartilhamento de informações com operadores cognitivos variados e a conexão em tempo real, independente da distância geográfica, reforçando mutuamente estes efeitos. Como dispositivo de comunicação interativo e comunitário é um meio privilegiado do desenvolvimento da inteligência coletiva da multidão. Uma das condições para esta implantação é o desenvolvimento do conceito de virtualidade, ou seja, o encorajamento de uma comunicação contínua com o digital, que já existia através do telefone, rádio e televisão, que se dava de maneira recíproca, assíncrona e a distância. $\mathrm{O}$ que mudou com o ciberespaço foi à capacidade de determinados grupos humanos se coordenarem, cooperarem, alimentarem e consultarem uma memória comum, praticamente em tempo real, ficando menos dependentes de lugares, horários e planejamentos a longo prazo.

Essa nova distribuição de espaços fluídica abre novos caminhos e os trabalhadores estão cada vez mais inseridos nesse processo. Com uma interação renovadora a sua interligação em rede reafirma uma autonomia própria e cria uma resistência às forças do nacionalismo e do fundamentalismo. Visualizamos no mundo vários movimentos coletivos independentes das entidades formadoras de opinião. Pessoas com novas idéias a partir de blogs independentes têm exercido um papel que pode organizar politicamente esta nova entidade abstrata que é a multidão. É difícil prever se este movimento se consubstanciará em uma verdadeira resistência ao 'status quo' consumista. Mas, nesse novo mundo o proletariado aparece como um novo poder, através da linguagem e comunicação interativa e imaterial forma a estrutura corporativa necessária para a sua libertação. Com um novo uso da ligação maquinal em rede como ferramentas biopolíticas atua como agente 
autônomo da produção. Em uma sociedade de controle informatizada que cria perfis de trabalhadores e consumidores discriminatórios, a multidão resgata sua identidade e toma de seus controladores o direito de fazer sua própria história coletiva.

\section{REFERÊNCIAS}

BAUMAN, Zygmunt. Vida para consumo: a transformação das pessoas em mercadorias. Traduçãode Carlos Alberto Medeiros. Rio de Janeiro: Jorge Zahar, 2007.

BENTHAM, Jeremy. O panóptico. Tradução de Tomaz Tadeu da Silva. Belo Horizonte: Autêntica, 2000.

DEBORD, Guy. A sociedade do espetáculo. Tradução de Estela dos Santos Abreu. Rio de Janeiro: Contraponto, 1997.

DELEUZE, Gilles. Controle e devir. Conversações, São Paulo, Editora 34, 1990 .

. Post-scriptum: sobre as sociedades de controle. Conversações, São Paulo, Editora 34, 1990.

FOUCAULT, Michel. Vigiar e punir: nascimento da prisão. Tradução de Lígia M. Ponde Vassalo. Petrópolis: Vozes, 1977.

. A sociedade disciplinar em crise (1978). In: MOTA, Manoel Barros da (Org.). Ditos e escritos IV: estratégia, poder-saber. Tradução de Vera Lúcia A. Ribeiro. Rio de Janeiro: Forense Universitária, 2003.

. Em defesa da sociedade. Tradução de Maria Ermantina Galvão. São Paulo: Martins Fontes, 2005.

História da sexualidade I: a vontade de saber. Rio de Janeiro: Graal, 1979.

. Subject and Power. In: Dreyfuss, H. \& Rabinow P. Beyond strucutalism and hermeneutics. Bringhton, The Harvester Press apud MAIA, Antonio C. Sobre a analítica do poder de Foucault. Tempo Social; Ver. Social. USP: São Paulo, 7(1-2):83-103, outubro de 1995. 
FUKUYAMA, F. O fim da história e o último homem. Rio de Janeiro: Rocco, 1992.

GUATTARI, Félix. Caosmose: um novo paradigma estético. São Paulo: Editora 34, 1992.

HARDT, M. A sociedade mundial de controle. In: ALLIEZ, E. Deleuze. Uma vida filosófica. São Paulo: Editora 34.

HARDT, Michael; NEGRI, Antonio. Império. Tradução de Berilo Vargas. Rio de Janeiro: Record, 2010

KANAAN, Hamen. O fim da história e o último homem. Disponível em:

$<$ http://www.periodicos.udesc.br/index.php/percursos/article/viewFile/14

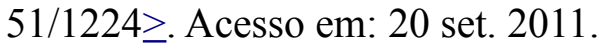

MAIA, Antonio C. Sobre a analítica do poder de Foucault. Tempo Social; Ver. Social. USP: São Paulo, 7(1-2):83-103, out. 1995.

MILLER, Jacques-Alain. A máquina panóptica de Jeremy Bentham. In: BENTHAM, Jeremy. O panóptico. Tradução de Tadeu da Silva. Belo Horizonte: Autêntica, 2000.

PASSETTI, Edson. Segurança, confiança e tolerância, comandos na sociedade de controle. São Paulo: Perspec, mar. 2004, vol.18, n.1.

WERRET, Simon. Potemkim e o Panóptico: Samuel Bentham e a arquitetura do absolutismo na Rússia do século XVIII. In: BENTHAM, Jeremy. O panóptico. Tradução de Tomaz Tadeu da Silva. Belo Horizonte: Autêntica, 2000. 